\title{
Fifty-Five Years of the Teaching of Informatics at Latvian Schools
}

\author{
Viesturs VEZIS, Ojars KRUMINS \\ Faculty of Computing, University of Latvia, Raina bulv. 19, LV-1586, Riga, Latvia \\ viesturs.vezis@lu.lv, zm33068@lu.lv
}

\begin{abstract}
This paper is devoted to the history of informatics as a topic of study, making note of the fact that 55 years have passed since it was introduced at some schools, 33 years since it was introduced at all schools, and 15 years since a scholarly approach to educational content in informatics was offered and introduced at Latvian schools. The paper has two sections: 1) a review of the content of the topic and its implementation up until 2002, as based on available sources from the literature, as well as interviews with witnesses from that era; 2) an overview of the development, implementation and monitoring of new educational content that was introduced in 2002 .
\end{abstract}

Keywords: didactics of computer science, informatics, education.

\section{Informatics studies and content thereof in Latvian schools, 1963-2002}

\subsection{Origins of the study of informatics in Latvia}

The origins of informatics studies in Latvia relate to activities at that time in the Soviet Union. On February 25, 1963, a collegium at the Soviet Latvian Ministry of Education issued a decree to say that as of the 1963/1964 school year, five schools in Latvia would offer classes focused on in-depth study of mathematics and physics. These were the No 1 High School in Riga, the No 2 Boarding School in Riga, the No 1 High School in Liepaja, the No 2 High School in Liepaja, and the No 1 High School in Daugavpils. The curriculum in this area included a new topic of study, "Computing mathematics and programming." This topic was taught for one lesson (45-minute) each week at upper classes at the high school level (IZM, 1963; IZM, 1965; IZM, 1967; IZM, 1970; IZM, 1972; IZM, 1973; IZM, 1974; IZM, 1975; IZM, 1976; IZM, 1977; IZM, 1978). The classes were organised in accordance with technical capabilities, because co-operation with computer centres was fairly weak. Information about computers, for instance, was sometimes limited to a single visit to a computer centre.

In 1971, Pēteris Zarinšs published a book, "Programmēšana vidusskolā" (Programming at High Schools), which was meant for students from the $9^{\text {th }}$ to the $11^{\text {th }}$ grade so that they could learn programming as an extracurricular activity, as well as in 
classes with in-depth studies of mathematics and physics. The book was aimed at developing the algorithmic thinking of students, including the following topics:

- Numeral systems and links between them;

- The structure and operating principles of computers;

- Preparation and recording of information processing algorithms (arithmetic operations, branching, cycles);

- Programming for the BESM-2 computer;

- Examples of programmes for simple approximate methods.

Beginning in the 1980/1981 school year, three lessons per week for "working training" were offered for classes with in-depth studies in physics and mathematics at all high schools. These lessons involved practical approaches to physics and mathematics, as well as work with computers, though, sadly, not at all schools. For classes with indepth theoretical and practical teaching of math's and physics, the "Programming and computing mathematics" subject was also preserved, with one lesson per week in each high school's class (IZM, 1981; IZM, 1984; IZM, 1985). Informatics studies on the basis of the aforementioned educational programmes began in the 1985/1986 and ended in the $1987 / 1988$ school year. It must be noted here that since the late 1970s, a high school textbook, "Algebra and Elements of Mathematical Analysis," had a chapter on computing equipment and the ALGOL programming language.

\subsection{Informatics as a new and mandatory educational topic for high school students in Latvia}

Thanks to the work of academician Andrei Yershov, all Soviet secondary education institutions, including those in Latvia, introduced a new study topic, "Fundamentals of Informatics and Computer Equipment," in the 1985/1986 school year (IZM, 1985).

The programme and its methodological instructions suggested that the topic be taught for one lesson (45-minute) per week in the $10^{\text {th }}$ grade and one or two lessons (45minute) in the $11^{\text {th }}$ grade, depending on whether the school did or did not have computer equipment. The lesson plan included the following topics:

- Introduction (fundamental concepts);

- Algorithms and algorithmic languages;

- Algorithms for work with values;

- Preparation of algorithms to solve problems;

- The structure and operational principles of computers;

- Introduction to programming;

- The role of computers in society, and prospects for the development of computing equipment;

- A field trip to a computer centre.

The emphasis in this programme was on developing the algorithmic thinking of students, the preparation and analysis of algorithms, theoretical programming languages, solving of problems, as well as an examination of the structure and operating principles of computers. At schools where computer equipment was available, $11^{\text {th }}$ grade students had 34 additional lessons (45-minute) during which students handled various practical tasks in relation to computers. Appropriate textbooks were made available, and this was one of the very rare cases in the USSR when in addition to the only "acceptable" 
textbook that was translated from the Russian, schools were officially allowed to use educational content in the field of informatics that was prepared by Latvian authors Agnis Andžāns, Uldis Grīnfelds, and Ēvalds Ikaunieks. Both textbooks for the $10^{\text {th }}$ grade (Andžāns et al., 1985; Jeršovs et al., 1986) were in line with the curriculum in terms of their content, while in the $11^{\text {th }}$ grade, the textbook that was more appropriate to teach algorithms and programming on a theoretical basis was the one that was edited by Yershov and V. Monakhov (Jeršovs et al., 1986). A book edited by Grīnfelds was appropriate to teach programming and to offer various computer-related problems for home works (Andžāns et al., 1986).

Delivery of computer equipment to Latvia's schools began in 1987. The set usually included twelve BK-type computers for students and a DVK computer and printer for the teacher. The computers were linked in a local network. Latvia was the republic in the Soviet Union in which nearly all high schools had at least one computer classroom of this type. This meant that the topic "Fundamentals of Informatics and Computer Equipment" moved from the theoretical plane without a computer to the use of actual computer equipment. As the availability of computers at schools increased (Table 1), and as computers were increasingly used in various sectors of the Soviet economy, it became necessary to review the teaching programme to improve the teaching of informatics.

Table 1. Numbers of computers at the beginning of each school year in Latvia (data from Ministry of Education)

\begin{tabular}{|l|c|c|c|c|c|}
\hline Date & $\mathbf{1 . 0 9 . 1 9 8 5}$ & $\mathbf{1 . 0 9 . 1 9 8 6}$ & $\mathbf{1 . 0 9 . 1 9 8 7}$ & $\mathbf{1 . 0 9 . 1 9 8 8}$ & $\mathbf{1 . 0 9 . 1 9 8 9}$ \\
\hline $\begin{array}{l}\text { Computer } \\
\text { classrooms }\end{array}$ & 5 & 23 & 58 & & 200 \\
\hline Computers & 60 & 276 & 696 & \multirow{2}{*}{ No data } & 2,400 \\
\cline { 1 - 4 } $\begin{array}{l}\text { \% of schools with } \\
\text { computers }\end{array}$ & 1.5 & 6.9 & 17.0 & & 58.7 \\
\cline { 1 - 4 } $\begin{array}{l}\text { \% of students with } \\
\text { access to computers }\end{array}$ & 15 & 52 & 88 & & 98 \\
\hline
\end{tabular}

Starting from the 1989/1990 school year, the topic "Informatics and Computer Equipment" was taught for two lessons per week during the first year of high school students (the $10^{\text {th }}$ grade at that time), while schools with in-depth teaching of physics and mathematics had an additional one lesson per week at the $11^{\text {th }}$ grade (IZM, 1989a). The new basic programme (IZM, 1989b, IZM, 1989c) included not just algorithms and programming, but also various software and the following topics:

- Fundamental concepts;

- The history of computers and their importance in present-day society;

- The structure and operating principles of computers;

- Algorithms and their construction;

- Introduction to programming;

- Use of computers to solve information processing problems:

- Text editing;

- Graphics editing;

- Databases;

- Electronic tables; 


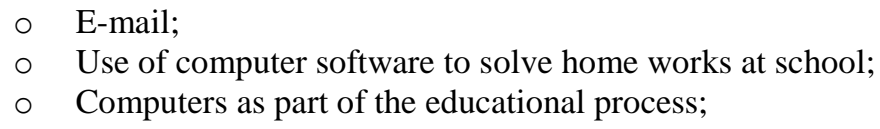

All of this was possible thanks not just to the availability of computer equipment, but also to the fact that the School and University Informatics Laboratory at the Institute of Mathematics and Computer Science, University of Latvia had produced software for BK - type computers (a text and graphics editor, a database, electronic tables). Jurijs Kuzmins developed learning software system RIGA.

Under the leadership of Jānis Bičevskis, the Chair of Discrete Mathematics and Programming at the University of Latvia, organized an educational programme of 102 lessons (IZM, 1989b) to provide more in-depth teaching in the fundamentals of informatics and computer equipment, as well as more in-depth teaching in the fields of physics and math's. The following themes were included:

- Introduction (fundamental concepts);

- Fundamentals of work with a computer;

- Information and its coding;

- The structure and operating principles of computers;

- Algorithms;

- Programming;

- Practical classes in programming;

- Mathematic modelling and solving of scientific, technical and economic problems with the use of computers.

This programme, unlike the base programme, focused more attention on programming, mathematical models and solving various problems and less attention to application software. The programme suggested that the deeper study of the topic could only be possible in extracurricular activities, the recommendation being to deal with the following topics:

- Optimisation of algorithms;

- Proving the correctness of algorithms;

- Problems that cannot be resolved by algorithms;

- Programming languages;

- Information exchange in a computer;

- Information storage devices;

- Computers in physics experiments.

In 1990, the topic "Fundamentals of Informatics and Computer Equipment" was renamed and became "Informatics" (IZM, 1990b). Along with the change in the programme, the content was also differentiated during the 1990/1991 school year (IZM, 1990a):

- "An Informatics Programme for General Education High Schools," 68 lessons, designed by Līga Andersone and Māris Vītinšs;

- "An Informatics Programme for Humanities Classes," 34 lessons, designed by the University of Latvia's Department of Fundamental Informatics and Technical Educational Resources, led by Andris Kangro;

- "An Informatics Programme for Profile Classes in Mathematics and Physics," 102 lessons, designed by the Chair of Discrete Mathematics and Programming at the University of Latvia. 
Thus began a differentiation in the approach toward informatics classes in Latvia. Students pursuing the humanities learned about application software, those who specialised in maths and physics were taught in-depth programming and algorithm design, while students in general education classes made use of application software with a look at programming and algorithms. In 1990/1991, for the first time, an experimental informatics course for elementary schools was offered at the Liepaja Pedagogic Institute and taught by Dzintra Krūče (IZM, 1990a). The course covered 34 lessons.

\subsection{Development of informatics as a study topic and challenges since the restoration of Latvia's independence}

Beginning in the 1991/1992 school year (IZM, 1991), high schools in Latvia introduced a course system which basically destroyed not just the subject of exact sciences, but also the learning of informatics. These were ill-considered reforms, because most subjects, including informatics, became electives, with students being allowed to choose the ones that were of interest to them. Often the decisive factor was whether it would be easier to get a good grade in a specific subject area, as opposed to a more difficult one. A few years later, the teaching programme system was reintroduced, but some losses were all but irreversible, including a cut in the number of lessons used to teach math's and the exact sciences. Between 1991 and 1997, there was a decline in the development of the topic of informatics, as well as in the computerization of schools. Completely out of date computers make it impossible to work with new software, and the work largely depended on the enthusiasm of certain schools and teachers. Data gathered by the Ministry of Education and Science in 1996, for instance, showed that among 13,628 $12^{\text {th }}$ grade students in the country, informatics as a basic course of study had been chosen by 3,962 students (29\%), and as a profile course by $3,393(25 \%)$.

It must be said that there were a few positive aspects to the reforms, including the fact that each area of study could have basic courses and profile courses (IZM, 1991; IZM, 1992; IZM, 1993b; IZM, 1994; IZM, 1995c; IZM, 1996; IZM, 1997c). The recommendation was that informatics courses should cover 70 lessons at the level of basic courses and 210 lessons at the level of profile courses (IZM, 1993a; IZM, 1995a). On May 6, 1993, the Education Ministry approved Instruction No 237 to set secondary education standard in the field of informatics (IZM, 1993c), and on December 22, 1995, the Education Content and Examination Centre (ISEC) approved Instruction No 101 to confirm guidelines for informatics profile courses (IZM, 1995a). Analysis of these two instructions leads to the following conclusions:

- The high school standard in the field of informatics established in 1990 was preserved with nonessential corrections taking into account the problems faced by general education high schools;

- The guidelines for informatics profile courses were based on requirements related to informatics, math's and physics profile classes, and standard requirements have been substantially deepened and expanded.

When Latvia regained its independence and business operations began to develop, computers increasingly became a component of offices, and this fact meant the need to learn about various application (office) software to process images or texts, produce sheets of texts and databases, as well as the use of Internet services. BK - type computers 
were gradually replaced with IBM - compatible computers that allowed students to learn about application (office) software that was in demand in the labour market. In the 1995/1996 school year, a new topic was introduced in high schools -- "Applied informatics" (IZM, 1995b; IZM, 1995c). This only applied to schools that had IBM compatible computers. The new topic offered basic course standards (IZM, 1997a) and profile course guidelines (IZM, 1995b). The standard for the applied informatics class was approved on December 22, 1988 via Instruction No 98/21 from the National Centre for Education (IZM, 1999a), while guidelines for profile courses were approved on August 5, 1997, via Instruction No 44 from the ISEC (IZM, 1997b). Although the profile course of applied informatics had to be deeper and expanded, the sad fact is that the requirements in the two documents included no differences. They also did not offer indications as to the level of detail at which the indicated software had to be learned. The two documents covered the following topics:

- Information and related processes, computers;

- Text processing;

- Graphic editors;

- Database management systems;

- Table processors;

- Computer networks;

- Multimedia systems.

Teachers used a textbook on applied informatics that was written by Kārlis Veiss. There was also a sample programme for profile courses in the area of applied informatics.

In 1997, thanks to a Latvian education informatisation system (LIIS), the study of informatics gradually recovered its positions in schools, because schools received modern computers, as well as complex informatisation of the entire education system. This included an ongoing training system for teachers in the field of information and communication technology, led by Viesturs Vēzis (Miķelsons et al., 2005a; Miķelsons et al., 2005b; Bicevskis et al., 2004). By 2004, nearly all informatics teachers had taken these professional competence courses, with $70 \%$ of teachers who teach other subjects having improved their computer skills.

\section{The first educational content based on scholarly justifications at Latvia's schools}

\subsection{Four new education standards in the field of informatics}

In 2002, on the basis of international experience, the needs of the labour market and the public, as well as the availability of computer equipment and informatics teachers at Latvian schools, a computer study strategy was established in Latvia (Bičevskis et al., 2002; Bičevskis et al, 2003a, Bičevskis et al, 2003b). A working group led by Vēzis was established to draft new standards and sample teaching programmes for the new informatics classes. This applies to elementary schools and high schools. As a result of this, the Latvian Ministry of Education and Science has given four education standards and sample teaching programmes in line with those standards for elementary and high 
school education: the basic education standard in informatics, the high school standard for informatics in a transitional period, a high school education standard in Informatics I, and a high school education standard in informatics II.

The secondary education standard in Informatics I stated that all high school students will obtain a European Computer Driving License (ECDL, a certification in the practical use of computers and computer applications) as part of the full programme, while the standard for Informatics II was oriented to maths and natural sciences so that students learn about algorithms and learn the fundamentals of programming.

A way had to be found how to include the educational standards into educational programmes. On July 3, 2003, the National Centre for Education issued Instruction No 55 to accept two of the four standards -- "Informatics, basic education standard" and "Informatics, secondary education standard for the transitional period." These were introduced by Instruction No 344, which the Latvian Ministry of Education and Science issued on July 16, 2003. From the 2003/2004 school year, both standards were transitional, and for three years the elementary education standard was first offered in the $7^{\text {th }}$ grade and then the $8^{\text {th }}$ and $9^{\text {th }}$ grade. Two transitional periods were established. Students in elementary school studied informatics in all three of those grades, while the secondary education informatics standard involved 70 and 140 lesson programmes, depending on the previous preparation of the students. The full implementation of the elementary education standard of informatics began in the 2004/2005 school year with the $5^{\text {th }}$ grade and then the $6^{\text {th }}$ and $7^{\text {th }}$ grade, also meaning that the knowledge and skills would be used in other classes in the $8^{\text {th }}$ and $9^{\text {th }}$ grade.

The elementary education standard in informatics involves the following educational content:

- Fundamental concepts related to information and communications technologies;

- Practical and research work:

- The use of computers and files;

- Processing of images;

- Processing of texts;

- Use of spreadsheets;

- Preparation and demonstration of presentation materials;

- Use of information and communications resources;

- Practical work with devices and information about the student's security and that of others.

The secondary education standard for informatics included all of the requirements related to obtaining the European Computer Driving License, and this involved the following content:

- Fundamental concepts related to information and communications technologies;

- Practical and research work:

- The use of computers and files;

- Processing of images;

- Processing of texts;

- Use of spreadsheets;

- Preparation and use of databases;

- Preparation and demonstration of presentation materials;

- Use of information and communications resources; 
- Practical work with devices and information about the student's security and that of others.

Each high school student who completed the informatics course was given an opportunity to take tests to obtain an internationally recognized European Computer Driving License.

When the law on national governance was amended in 2006, the content of education at schools was determined by Cabinet of Ministers regulations. The standards made no changes in terms of content, but they were included in Cabinet of Minister regulations on standards related to elementary and secondary education subjects. On December 19, 2006, the Cabinet approved Regulation No 1027, "Basic education standard," which included the aforementioned standard on elementary education in informatics. On August 7, 2007, Cabinet of Ministers Regulation No 544, "General secondary education standard," included the two remaining 2002 standards, "Informatics, the general secondary education subject standard" (implemented on September 1, 2006), and "Fundamentals of programming, the general secondary education subject standard" (implemented on September 1, 2007).

As was the case with the transitional period of the secondary education standard in informatics, the new "Informatics, general secondary education subject standard" included all of the requirements that were needed to obtain the European Computer Driving License. In addition to learning about the professional graphics editing and the design of Webpages, the following content was mandatory:

- Fundamental concepts related to information and communications technologies;

- Practical and research work:

○ The use of computers and files;

- Processing of imagesprofess sw;

- Processing of texts;

- Use of spreadsheets;

- Preparation and use of databases;

- Preparation and demonstration of presentation materials;

- Use of information and communications resources;

- Design of Webpages;

- Practical work with devices and information about the student's security and that of others.

"Fundamentals of programming, general secondary education subject standard," in turn included the following mandatory content:

- Information and its processing;

- Practical and research work:

- Programming languages;

- Algorithms and data structures;

- Design of computer-based systems;

- Practical work with devices and information about the student's security and that of others.

The sad fact is that these Cabinet of Ministers regulations did not include the subject of fundamental programming in mandatory elective classes as part of one of the four standard education programmes. Each school has to decide whether the fundamentals of programming are to be taught to students. 
The Cabinet of Ministers has occasionally issued new regulations about elementary and general secondary education standards, but the content of courses in informatics and the fundamentals of programming have remained unchanged. The latest version of the subject standard and sample educational programmes can be found at the National Centre for Education (http://www.visc.gov.lv).

\subsection{Introduction and development of new educational content in informatics}

In 2002, a group led by Viesturs Vēzis established subject standards and sample educational programmes that were meant to gradually increase the level of knowledge and skills among high school graduates. This is evidenced by annual measurements that are used to analyse the final exams of all Latvian high school students in the area of informatics. Each year the process uses the same methodology, and the level of difficulty during each exam can be compared to levels in other years.

A review of the final exams in informatics in 2003 (2004 data were not available) shows that only $30 \%$ of students received a grade of 7 or more on a 10-point scale. In 2005 and 2006, the exam was taken only by those students who had studied informatics on the basis of new standards and educational standards, and the results were much better in that $50 \%$ of them got a grade of 7 or more.

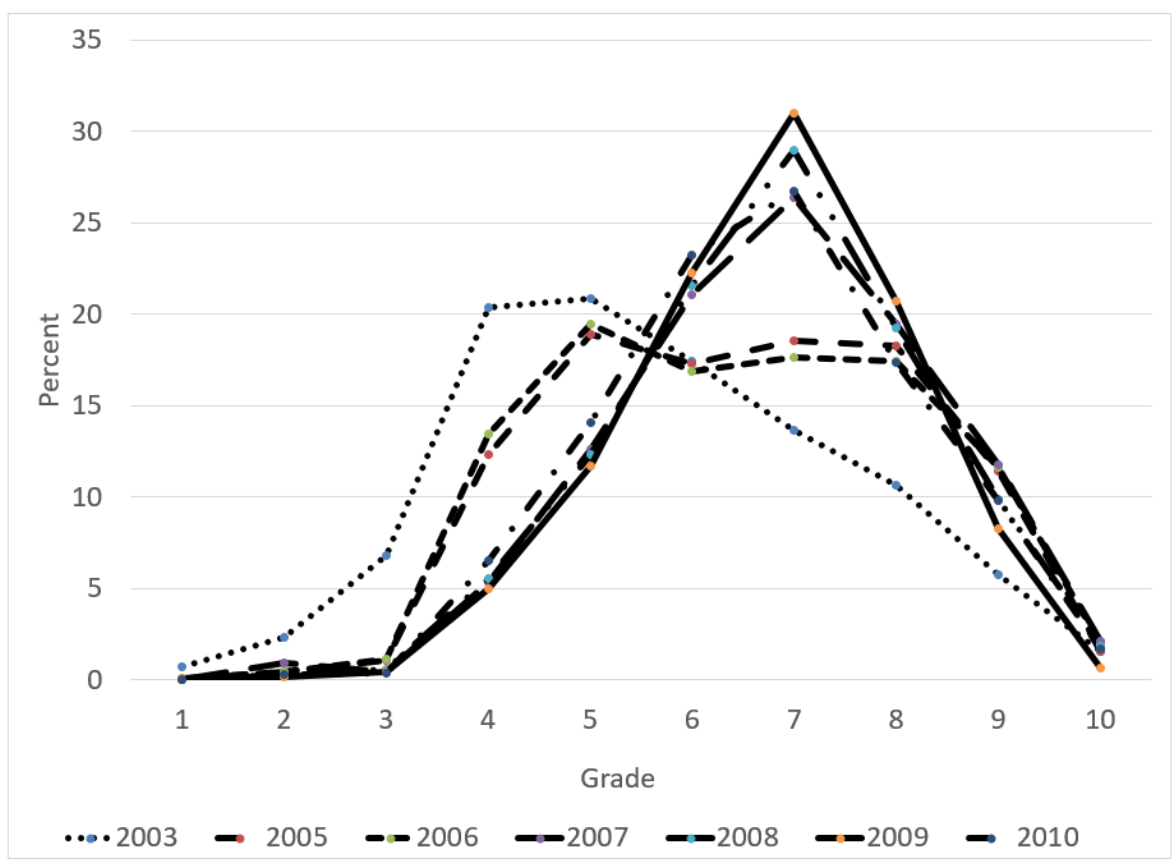

Figure 1. The percentage-based distribution of grades received by students between 2003 and 2010 (data from National Centre for Education) 
Between 2007 and 2010, final exams in informatics were taken by all high school students who had studied informatics for three years in elementary school on the basis of the new standards and sample programmes. These students posted even better results, with $57 \%$ to $62 \%$ of high school students receiving a grade of 7 or more. A more detailed look at the results of the exams between 2003 and 2010 can be seen in Figure 1.

Figure 1 shows that the distribution of grades is close to the Gaussian distribution, which suggests that the education standards and sample programmes in informatics, as well as the content of the final exam (132 tasks that are evaluated independently and are divided up into four segments, with 45 minutes given to complete each segment) were optimal.

Monitoring of the content of informatics classes between 2011 and 2017 shows that final exam results were even better (Figure 2), but these cannot be objectively compared to the data in Figure 1, because since 2011, the final exam in informatics has not been mandatory for all students, and only $20 \%$ to $40 \%$ of high school students have chosen to take it.

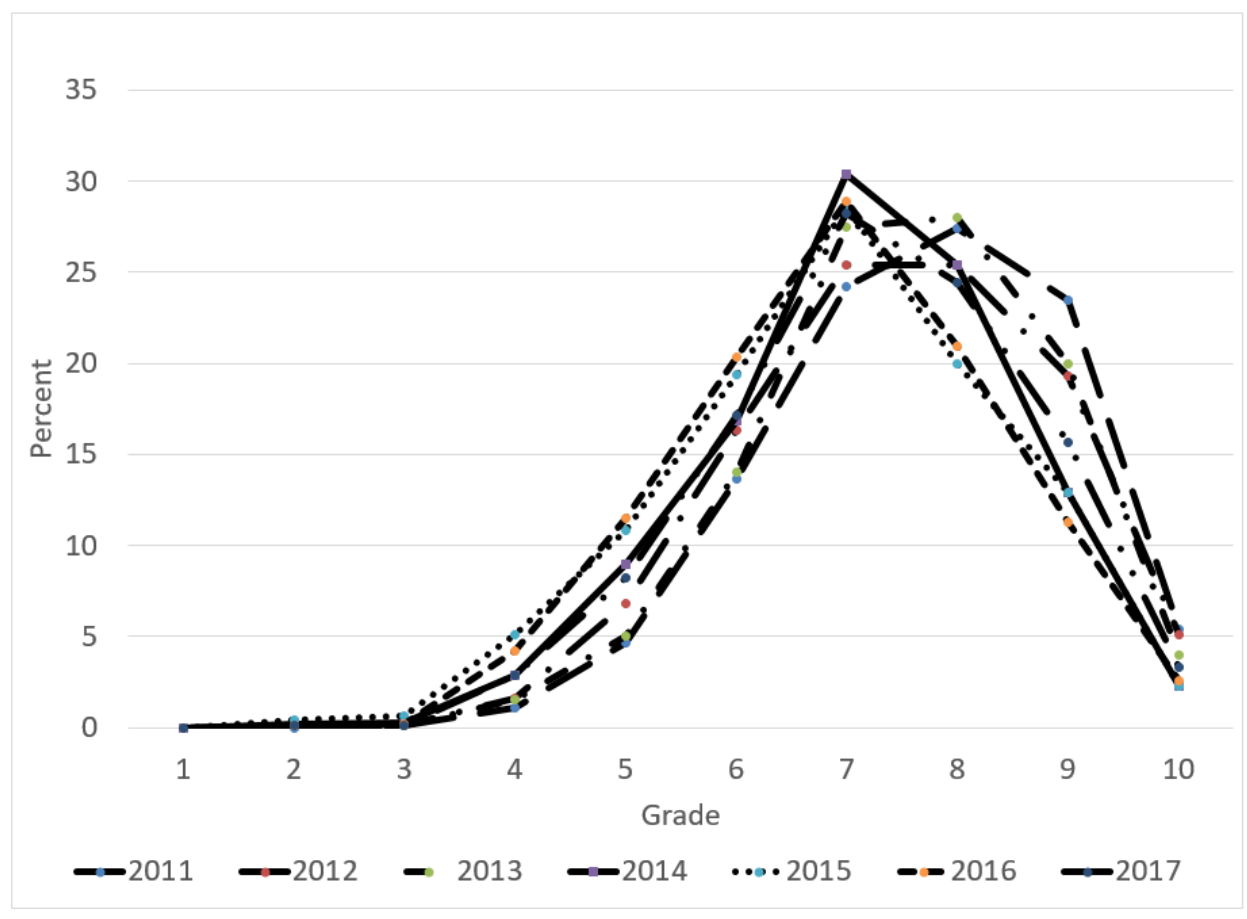

Figure 2. The percentage-based distribution of grades received by students between 2011 and 2017 (data from National Centre for Education)

In conclusion, it must be noted that the educational content that was designed under the leadership of Viesturs Vēzis for elementary and secondary education, the educational programmes that were implemented, methodological support and the schedule for introducing the courses were optimal and have proven themselves over the course of 15 years. For more than three years, however, the authors of this paper have been working on new content for informatics classes. A separate paper will be written about that. 


\section{References}

Andžāns A., Grinfelds U., Ikaunieks Ē. (1985). Informātika: Mācību līdzeklis vidusskolu 10. klasei (In English: Informatics: An Educational Resource for High School Students in the 10th Grade), Zvaigzne, Rīga.

Andžāns A., Grinfelds U., Ikaunieks Ē. (1986). Informātika: Mācību līdzeklis vidusskolu 11. klasei (In English: Informatics: An Educational Resources for High School Students in the $11^{\text {th }}$ Grade), Zvaigzne, Rīga.

Bicevskis J., Andzans A., Ikaunieks E., Medvedis I., Straujums U., Vezis V. (2004) Latvian education informatization system LIIS. Educational Media International, vol. 41., No 1, 4350 .

Bičevskis J., Straujums U., Vezis V. (2002) Datorzinību apguves stratēgija Latvijā. Izglītîba un kultūra, Nr 24, 12-14.

Bičevskis J., Straujums U., Vezis V. (2003a) Acquisition of Information and Communication Technologies at Schools of Latvia. Proceedings of Changing Education in a Changing Society Conference (9-10 May. 2003, Rīga, Latvia), Izglīîibas soḷi 2003, 174-182.

Bičevskis J., Straujums U., Vezis V. (2003b) Computer literacy acquisition strategy in Latvia: problems and solutions. Proceedings of Forum e-Baltic: Information Technologies and Telecommunications in the Baltic States Conference (2-5 Apr. 2003, Rīga, Latvia), Data Media Group, 2003, 173-176.

IZM (1963). Skolu mācību plāni 1963./64. m.g. skolām ar latviešu mācību valodu (In English: Lesson plans for schools, 1963/64, for schools with classes taught in Latvian), Rīga.

IZM (1965). Mācību plāni vispārizglītojošām skolām ar latviešu mācību valodu 1965./66. m.g. (In English: Curricula for general education schools with classes taught in Latvian, 1965/66), Rīga.

IZM (1967). Mācību plāni vispārizglītojošām skolām ar latviešu mācību valodu 1967./68. m.g. (In English: Curricula for general education schools with classes taught in Latvian, 1967/68), Rīga.

IZM (1970). Mācību plāni vispārizglītojošām skolām 1970./71. m.g. (In English: Curricula for general education schools, 1970/71), Rīga.

IZM (1972). Mācību plāni vispārizglītojošām skolām 1972./73. m.g. (In English: Curricula for general education schools, 1972/73), Rīga.

IZM (1973). Vispārizglītojošo skolu mācību plāni 1973./74/ m.g. (In English: Lesson plans for general education schools, 1973/74), Rīga.

IZM (1974). Mācību plāni 1974./75. (In English: Curricula, 1974/75), Rīga.

IZM (1975). Mācību plāni 1975./76. (In English: Curricula, 1975/76), Rīga.

IZM (1976). Mācību plāni 1976./77. (In English: Curricula, 1976/77), Rīga.

IZM (1977). Mācību plāni 1977./78. (In English: Curricula, 1977/78), Rīga.

IZM (1978). Mācību plāni 1978./79. (In English: Curricula, 1978/79), Rīga.

IZM (1981). Vispārizglītojošo skolu mācību plāni 1981./82. m.g. (In English: Lesson plans for general education schools, 1981/82), LPSR Izglītības ministrija, Rīga.

IZM (1984). Vispārizglītojošo vidusskolu mācību plāni 1984./85. m.g. (In English: Lesson plans for general education schools, 1984/85), LPSR Izglītības ministrija, Rīga.

IZM (1985). Vispārizglītojošo vidusskolu mācību plāni 1985./86. (In English: Curricula for general education high schools, 1985/86), LPSR Izglīīibas ministrija, Rīga.

IZM (1989a). Vispārizglītojošo vidusskolu mācību plāni 1989./90. m.g. (In English: Lesson plans for general education schools, 1989/90), LPSR Tautas Izglìtības ministrija, Rīga.

IZM (1989b). Informātikas un skaițlošanas tehnikas pamati: Eksperimentāla programma fizikas un matemātikas profilklasēm (In English: Fundamentals of informatics and computers: An experimental programme for profile classes in physics and mathematics), TIM, Rīga. 
IZM (1989c). Informātikas un skaiţ̦ošanas tehnikas pamati: Eksperimentāla programma 10. klasei (In English: Fundamental of informatics and computers: An experimental programme for the $10^{\text {th }}$ grade), TIM, Rìga.

IZM (1990a). Informātikas programmas (In English: Curricula of informatics), TIM, Rīga.

IZM (1990b). Vispārizglītojošo vidusskolu mācību plāni 1990./91. m.g. (In English: Lesson plans for general education schools, 1990/91), Latvijas Tautas Izglīīibas ministrija, Rīga.

IZM (1991). Vispārizglītojošo vidusskolu mācību plāni 1991./92. m.g. (In English: Lesson plans for general high schools, 1991/92), Latvijas Republikas Tautas Izglīiības ministrija, Rīga.

IZM (1992). Vispārizglītojošo skolu mācību plāni 1992./93. m.g. (In English: Lesson plans for general education schools, 1992/93), Latvijas Republikas Izglìtības ministrija, Rīga.

IZM (1993a). Informātikas profilkursa vadlīnijas: Projekts (In English: Informatics profile course guidelines: draft), IKZM, Rīga.

IZM (1993b). Vispārizglītojošo skolu mācību paraugplāni 1993./94. m.g. (In English: Sample plans for general education schools, 1993/94), Latvijas Republikas Izglītības ministrija, Rīga.

IZM (1993c). Vispārējās izglītības standarts informātikā (In English: Standard of informatics for general education schools), IM, Rīga

IZM (1994). Skolu stundu paraugplāni 1994./95. mācību gadam (In English: Sample lesson plans for schools, 1994/95 school year), Latvijas Republikas Izglīîibas, kultūras un zinātnes ministrija, Rīga.

IZM (1995a). Informātika: Profilkursa vadlīnijas (In English: Informatics: profile course guidelines), Rīga.

IZM (1995b). Lietišksā informātika. Profilkursa vadlīnijas (projekts) (In English: Applied informatics: Profile course guidelines (draft)), Rīga.

IZM (1995c). Vispārizglîtojošo skolu mācību priekšmetu, kursu un stundu paraugplāni 1995./96. mācību gadam (In English: Sample plans for subjects, courses and lessons at general schools, 1995/96), Latvijas Republikas Izglīīibas un zinātnes ministrija, Rīga.

IZM (1996). Vispārizglītojošo skolu mācību priekšmetu un kursu stundu paraugplāni 1996./97. mācību gadam (In English: Sample plans for subjects, courses and lessons at general schools, 1996/97), Latvijas Republikas Izglīî̄ibas un zinātnes ministrija, Rīga.

IZM (1997a). Lietišksā informātika. Vidējās izglītības standarts (projekts) (In English: Applied informatics: Secondary education standard (draft)), LR IZM ISEC, Rīga.

IZM (1997b). Lietišķā informātika. Profilkursa vadlīnijas (In English: Applied informatics: Profile course guidelines), LR IZM ISEC, Rīga.

IZM (1997c). Vispārizglītojošo skolu mācību priekšmetu un kursu stundu paraugplāni 1997./98. mācību gadam (In English: Sample plans for subjects, courses and lessons at general schools, 1997/98), Latvijas Republikas Izglītības un zinātnes ministrija, Rīga.

IZM (1999). Lietišķā informātika. Vidējās izglītîbas standarts (In English: Applied informatics: Secondary education standard), LR IZM ISEC, Rīga.

Jeršovs A., Monahovs V., Bešenkovs S. u.c. (1986). Informātikas un skaitḷošanas tehnikas pamati: 2 daḷās (In English: Fundamentals of Information and Computers, 2 volumes), Zvaigzne, Rīga.

Miķelsons J., Andžāns A., Bicevskis J.,Medvedis I., Niedra A., Straujums U.,Vēzis V., Trukšāns L. (2005a) ICT in Latvian Educational System-LIIS Approach. Edited by F.Malpica, F.Welsch, A.Tremante. Eista'05 Proceedings, vol. II, 94-98.

Mikelsons J., Andžāns A., Ikaunieks Ē., Niedra A., Straujums U., Trukšāns L., Vēzis V. (2005b) IKT aspekti Latvijas izglītības sistēmā. Edited by A. Andžāns, A. Cunska, L.Ramāna. Proceedings of The LatSTE'2005 Conference, Rìga, 55-60.

Received June 19, 2018, accepted June 19, 2018 